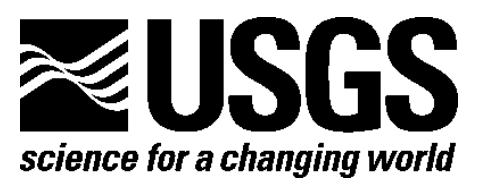

\title{
Chemistry of Selected Core Samples, Concentrate, Tailings, and Tailings Pond Waters: Pea Ridge Iron (-Lanthanide-Gold) Deposit, Washington County, Missouri
}

By Richard I. Grauch, Philip L. Verplanck, Cheryl M. Seeger, James R. Budahn, and Bradley S. Van Gosen

Open-File Report 2010-1080

U.S. Department of the Interior

U.S. Geological Survey 


\section{U.S. Department of the Interior \\ KEN SALAZAR, Secretary}

\section{U.S. Geological Survey \\ Marcia K. McNutt, Director}

U.S. Geological Survey, Reston, Virginia: 2010

For product and ordering information:

World Wide Web: http://www.usgs.gov/pubprod

Telephone: 1-888-ASK-USGS

For more information on the USGS-the Federal source for science about the Earth, its natural and living resources, natural hazards, and the environment:

World Wide Web: http://www.usgs.gov

Telephone: 1-888-ASK-USGS

Suggested citation:

Grauch, R.I., Verplanck, P.L., Seeger, C.M., Budahn, J.R., and VanGosen, B.S., 2010, Chemistry of selected core samples, concentrate, tailings, and tailings pond waters: Pea Ridge iron (-lanthanide-gold) deposit, Washington County, Missouri: U.S. Geological Survey Open File-Report 2010-1080, 15 p.

Any use of trade, product, or firm names is for descriptive purposes only and does not imply endorsement by the U.S. Government.

Although this report is in the public domain, permission must be secured from the individual copyright owners to reproduce any copyrighted material contained within this report. 


\section{Contents}

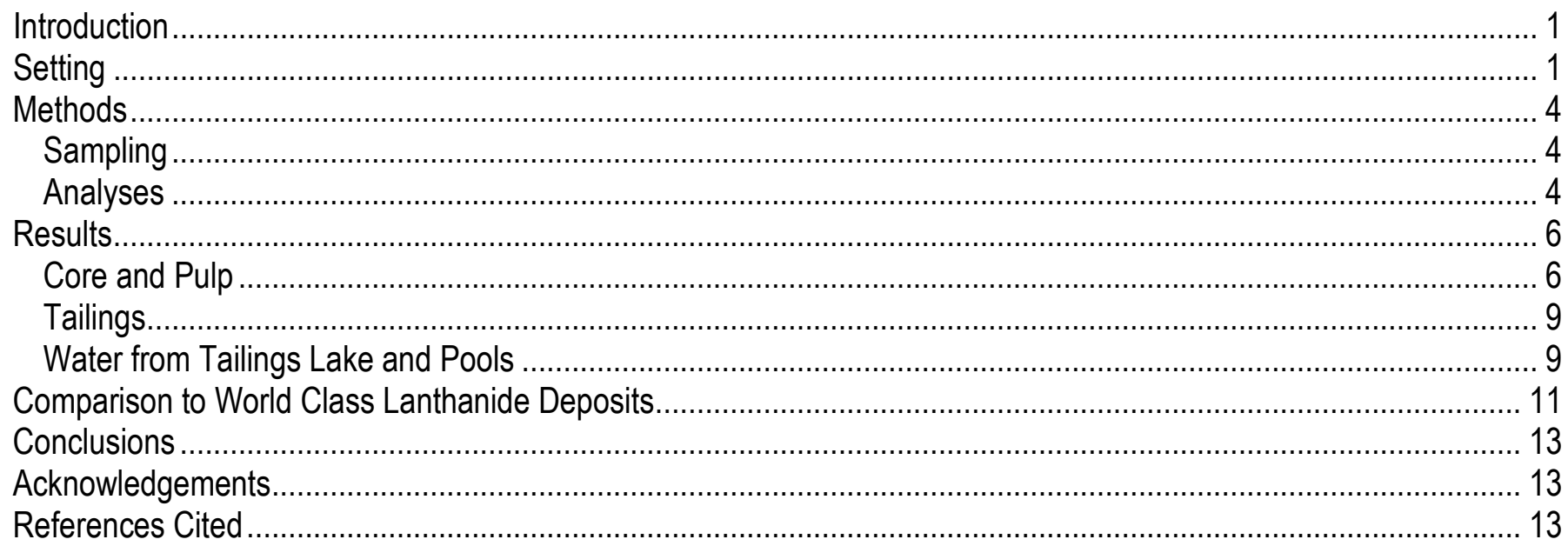

\section{Figures}

1. Location and generalized plan map of level 2275 showing location of the four lanthanide-bearing breccia pipes

2. Photograph showing small pool on tailings pile, Pea Ridge Mine, site of water sample $08 \mathrm{MO} 01$. Note orange alteration above and below water level and well-developed grasslands on reclaimed tailings in background. (P.L. Verplanck standing on the bank).

3. Photograph showing tailings lake, Pea Ridge Mine, site of water sample 08MO03. (C.M. Seeger, J. Kennedy, and A.N. Mariano (left to right), P.L. Verplanck kneeling far right).

4. Graph showing chondrite normalized $R E E+Y$ distribution patterns of core and pulp samples. ........................ 8

5. Graph showing chondrite normalized REE+Y distribution patterns of samples from the four I anthanide-bearing breccia pipes of the Pea Ridge deposit.

6. Graph showing chondrite normalized $R E E+Y$ distribution patterns of three tailings samples from the Pea Ridge deposit.

7. Graph showing chondrite normalized REE+Y distribution patterns of three water samples from

Pea Ridge tailings lake and pool......

8. Graph showing chondrite normalized REE $+Y$ distribution patterns of world-class lanthanide deposits and the Pea Ridge deposit..

\section{Tables}

1. Chemistry and descriptions of rock, pulp, and tailings samples from the Pea Ridge mine. . link

2. Chemistry and descriptions of water samples from pools on the tailings pile and the tailings lake at the Pea Ridge mine.

3. Composite REE+Y assays of the four lanthanide-bearing pipes of the Pea Ridge deposit. link

4. REE+Y oxide concentrations of three world-class lanthanide deposits and the Pea Ridge deposit. 7 12 


\title{
Chemistry of Selected Core Samples, Concentrate, Tailings, and Tailings Pond Waters: Pea Ridge Iron (-Lanthanide-Gold) Deposit, Washington County, Missouri
}

\author{
By Richard I. Grauch, Philip L. Verplanck, Cheryl M. Seeger, James R. Budahn, and Bradley S. Van Gosen
}

\section{Introduction}

The Minerals at Risk and for Emerging Technologies Project of the U.S. Geological Survey (USGS) Mineral Resources Program is examining potential sources of lanthanide elements [rare earth elements (REE)] as part of its objective to provide up-to-date geologic information regarding mineral commodities likely to have increased demand in the near term. As part of the examination effort, a short visit was made to the Pea Ridge iron (-lanthanide-gold) deposit, Washington County, Missouri in October 2008. The deposit, currently owned by Wings Enterprises, Inc. of St. Louis, Missouri (Wings), contains concentrations of lanthanides that may be economic as a primary product or as a byproduct of iron ore production. The specific objectives of the day and a half visit to the mine site and subsequent work were to: (a) meet with the owner (Jim Kennedy, president of Wings); (b) assess the availability of information, (c) obtain a few samples for analyses; and (d) begin a decision process regarding further studies of the deposit and its geologic setting. This report tabulates the results of chemical analyses of the Pea Ridge samples and compares REE contents for world class lanthanide deposits with those of the Pea Ridge deposit. The data presented for the Pea Ridge deposit are preliminary and include some company data that have not been verified by the USGS nor by the Missouri Department of Natural Resources, Division of Geology and Land Survey (DGLS), Geological Survey Program (MGS). The inclusion of company data is for comparative purposes only and does not imply an endorsement by either the USGS or MGS.

\section{Setting}

The Pea Ridge deposit is a member of the diverse class of iron oxide copper-gold deposits (IOCG deposits, Williams and others, 2005). It is one of several iron deposits located in southeastern Missouri (figure 1) within the Middle Proterozoic, volcano-plutonic complex of the St. Francois terrane. Host rocks of the iron ore body are altered rhyolite tuff (Nuelle and others, 1992). The deposit area includes the following mappable units: amphibole-quartz rock, heterolithic breccia, pseudobreccia, magnetite, hematite, silicified rock, lanthanide-bearing breccia pipes, mafic dikes, and aplite dikes (Seeger and others, 2001; Seeger, 2004, Nuelle and others, 1992). There are four mapped lanthanidebearing breccia pipes (X11, V12, X13, V14), which cross-cut the magnetite-hematite ore body and its altered rhyolite host rock (fig. 1). The pipes contain a variety of lanthanide-bearing minerals, including the principal ore minerals monazite and xenotime. Mineral paragenesis and alteration zones are described by Sidder and others (1993). Gold, tin, and silver are unevenly distributed in the breccia pipes and in both the hematite and silicified zones (Husman, 1989).

Mine production ceased in 2001 and the underground workings currently are flooded (2009). The property has two large tailings lakes flanked by extensive waste and tailings piles, most of which have been revegetated, along with several smaller ponds and wetlands. There also are several small, dry 
tailings ponds and a variety of ore stockpiles. Altogether there are approximately 180 acres (73 hectares) of waste and tailings (Jim Kennedy, oral commun., 2008).

The size of the lanthanide resource has not been determined. The REE-bearing breccia pipe dimensions are open downward. A copy of an internal company memo, provided by Jim Kennedy (electronic commun., October, 2008), dated 11-22-88 by Larry J. Tucker (retired Pea Ridge mine superintendent) indicates that there is a combined, probable reserve for pipes X11 and X13 of approximately 250,000 metric tons of mineralized rock, grading about 13 percent REE. The reserves were calculated for the volume between levels 2275 and 2675 using a density of 2,000 pounds per 9 cubic feet $\left(\mathrm{lb} / 9 \mathrm{ft}^{3}\right)$ [approximately 3.56 grams per cubic centimeter $\left.\left(\mathrm{g} / \mathrm{cm}^{3}\right)\right]$. The level numbers represent the depth in feet of the level below the collar of the mine shaft. Whitten and Yancey (1990) report that there are about 600,000 metric tons of REE mineralization with an average grade of approximately 12 percent rare earth oxide. It is not clear what data were used to determine the estimate of 600,000 metric tons. However, a similar, but not equal, value of 600,000 short tons occurs as a note on another internal company memo, provided by Jim Kennedy (electronic commun., October, 2008), dated 10-25-89 by Larry J. Tucker; supporting calculations for the estimate are missing. The tailings contain additional lanthanide resources, primarily because of inclusions of fine-grained, REE-bearing minerals, principally monazite and xenotime, within apatite. The apatite also contains minor amounts of REE in its structure and occurs in variable concentrations throughout the iron ore body (Vierrether and Cornell, 1993). 


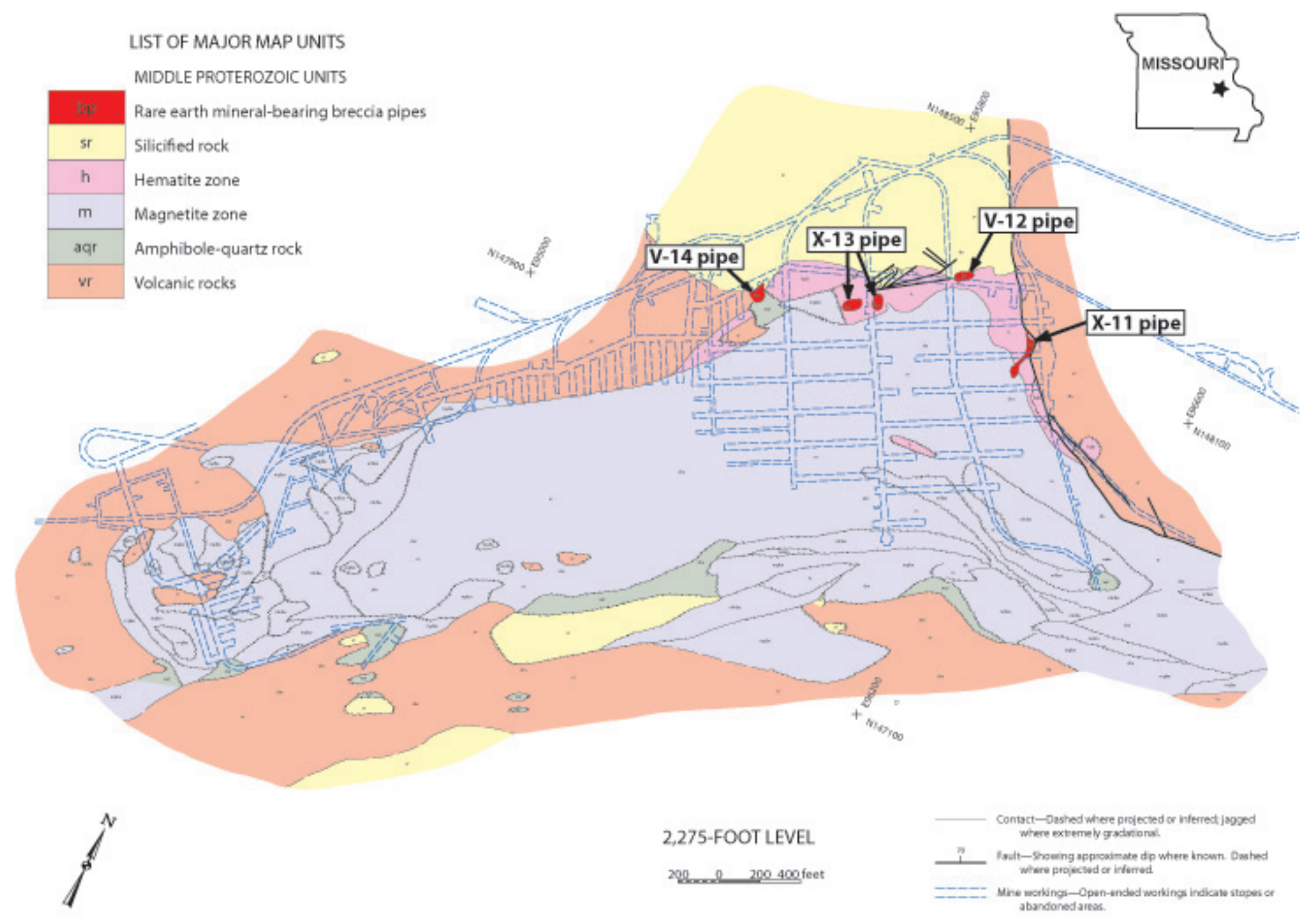

Figure 1. Location and generalized plan map of level 2275 showing location of the four lanthanide-bearing breccia pipes [Modified from Seeger (2004) and Seeger and others (2001)]. 


\section{Methods}

\section{Sampling}

Nine samples of core were collected in the Pea Ridge Mine-core shed. Eight of those were from diamond drill hole DDH 14, level 2275 and one from DDH 26, Block 962 (table 1). One core sample (DDH 6, level 2475) was collected from the DGLS McCracken Core Library in Rolla, Missouri. Gamma radiation from $T h$ and $U$ associated with lanthanide ore minerals was used as a guide to sampling high-grade lanthanide samples. Visual inspection guided the selection of representative samples of iron ore and waste material. A final sample was collected from a drum of slightly radioactive material labeled "pulps". The partially destroyed label appears to indicate that the pulps originated on the 2475 level (this level identification seems reasonable as level 2475 was one of the main focal points for lanthanide and gold exploration in the $1980 \mathrm{~s}$, which involved core and hammer drilling).

Surface waters were collected from two small pools on the waste and tailings pile and from the largest of the tailings lakes on the mine property (fig. 2 and 3). The three water samples were not filtered. Aliquots for cation determinations were acidified with ultrapure nitric acid.

Two samples of crushed rock from the waste and tailings pile and one from the tailings lake were given to the USGS by Wings. The samples were collected as part of a recent effort by Wings to evaluate the tailings piles, stock piles, and tailings lake. One of the samples is from one of several cores of tailings lake sediments and the other two samples are from trenches cut across the waste and tailings piles.

\section{Analyses}

Analytical data contained in this report were produced in-house by the USGS Central Region Mineral Resources Science Center Analytical Chemistry Project, which is administered by the Mineral Resources Program, and externally by SGS Laboratories (formerly XRAL) of Toronto, Canada. Descriptions of the SGS Laboratories' analytical methods, including detection limits can be found at: http://minerals.cr.usgs.gov/projects/analytical_chem/references.html.

The 10 core samples, pulp sample, and 3 samples of tailings and waste provided by Wings were analyzed by the SGS Laboratories " 55 element ICP-AES-MS sodium peroxide sinter" method (Inductively Coupled Plasma-Atomic Emission Spectroscopy-Mass Spectrometry). Additionally, the pulp and core samples were analyzed by SGS Laboratories' ICP major element analysis using lithium metaborate fusion method, by the USGS utilizing their Instrumental neutron activation by long count method (Budahn and Wandless, 2002), and by the USGS using a short irradiation instrumental neutron activation technique. The latter procedure is similar to that presented in Suzuki and Hirai (1987). The core samples were analyzed for Re and Te by Paul Lamothe (USGS) utilizing a four-acid digestion followed by ICP-MS analysis.

The tailings samples also were analyzed by the USGS wave-length dispersive X-ray fluorescence method (Taggart and Siems, 2002). Densities of the core samples were determined in the USGS Petrophysics Laboratory based on the weight and volume of the sample. Sample weights were determined using an analytical balance. Sample volumes were determined using the buoyancy method, which is based on Archimedes' principle (Hunt and others, 1979).

Analyses of the three water samples were completed in-house. Calcium, magnesium, potassium, sodium, sulfate, and silica and selected trace elements (aluminum, iron, and manganese) were 
determined using a Perkin Elmer Optima 3000 spectrometer (ICP-AES ${ }_{\mathrm{aq}}$; Briggs, 2002). Trace elements were analyzed by inductively coupled plasmamass spectrometry (ICP-MS $\mathrm{aq}$ ) using a method developed by the U.S. Geological Survey (Meier and others, 1994; Lamothe and others, 2002). This method is used to directly determine the elements in the water samples without need for any preconcentration or dilution. Alkalinity (as $\mathrm{HCO}_{3}{ }^{-}$) was determined using an Orion $960^{\mathrm{TM}}$ autotitrator and standardized $\mathrm{H}_{2} \mathrm{SO}_{4}$ (Barringer and Johnsson, 1989).

The analyses listed in tables 1 (solids) and 2 (water) include all of the data returned from the various laboratories. As a result, there are several cases where there is more than one determination for a given element. The preferred method and value (indicated in the table - green shading in the electronic form and gray shading in the printed form) generally are based on the method that provides the best precision and accuracy and a dissolution procedure that is most appropriate for the matrix of the sample being analyzed.

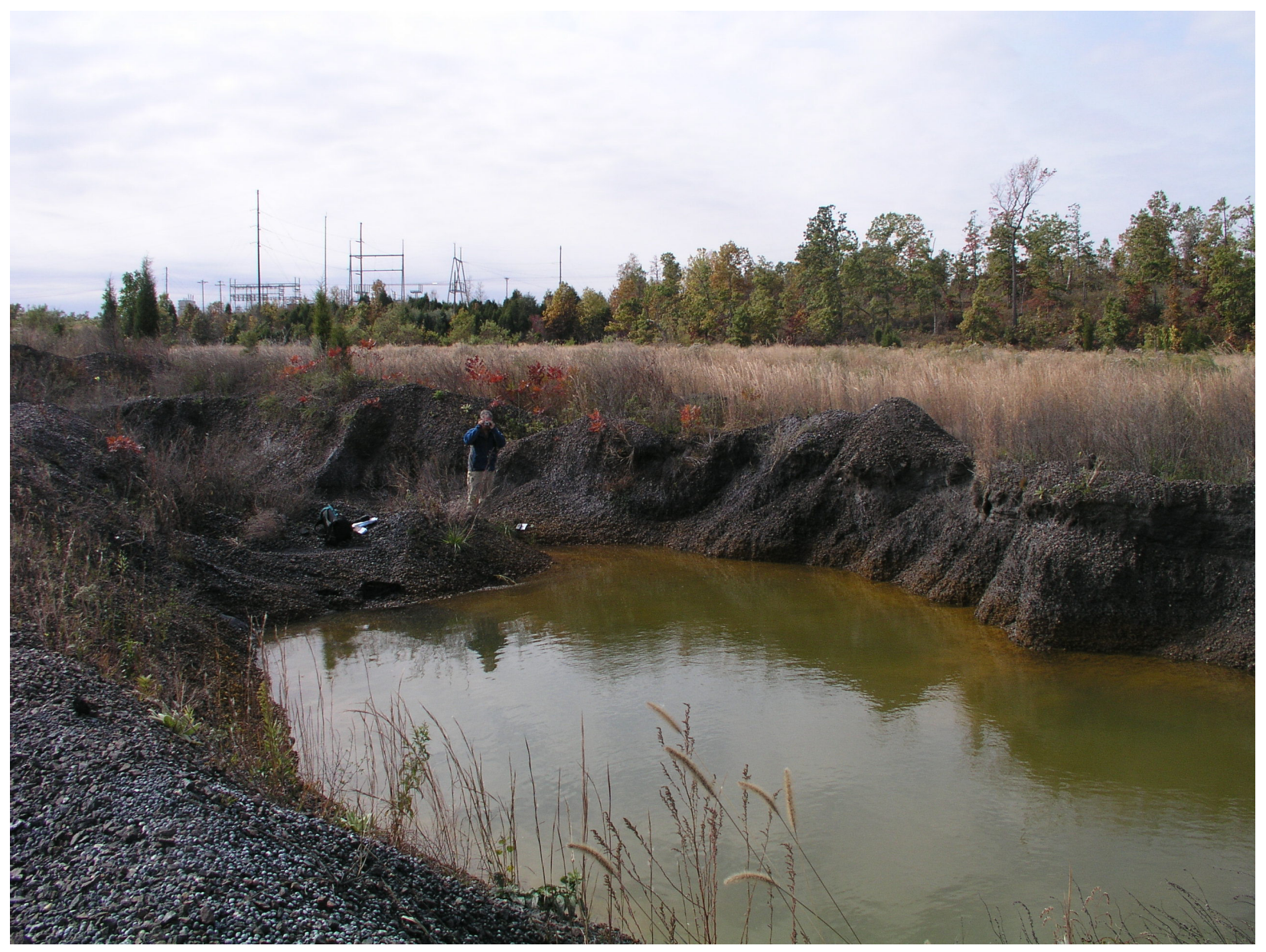

Figure 2. Small pool on tailings pile, Pea Ridge Mine, site of water sample 08MO01. Note orange alteration above and below water level and well-developed grasslands on reclaimed tailings in background. (P.L. Verplanck standing on the bank). 


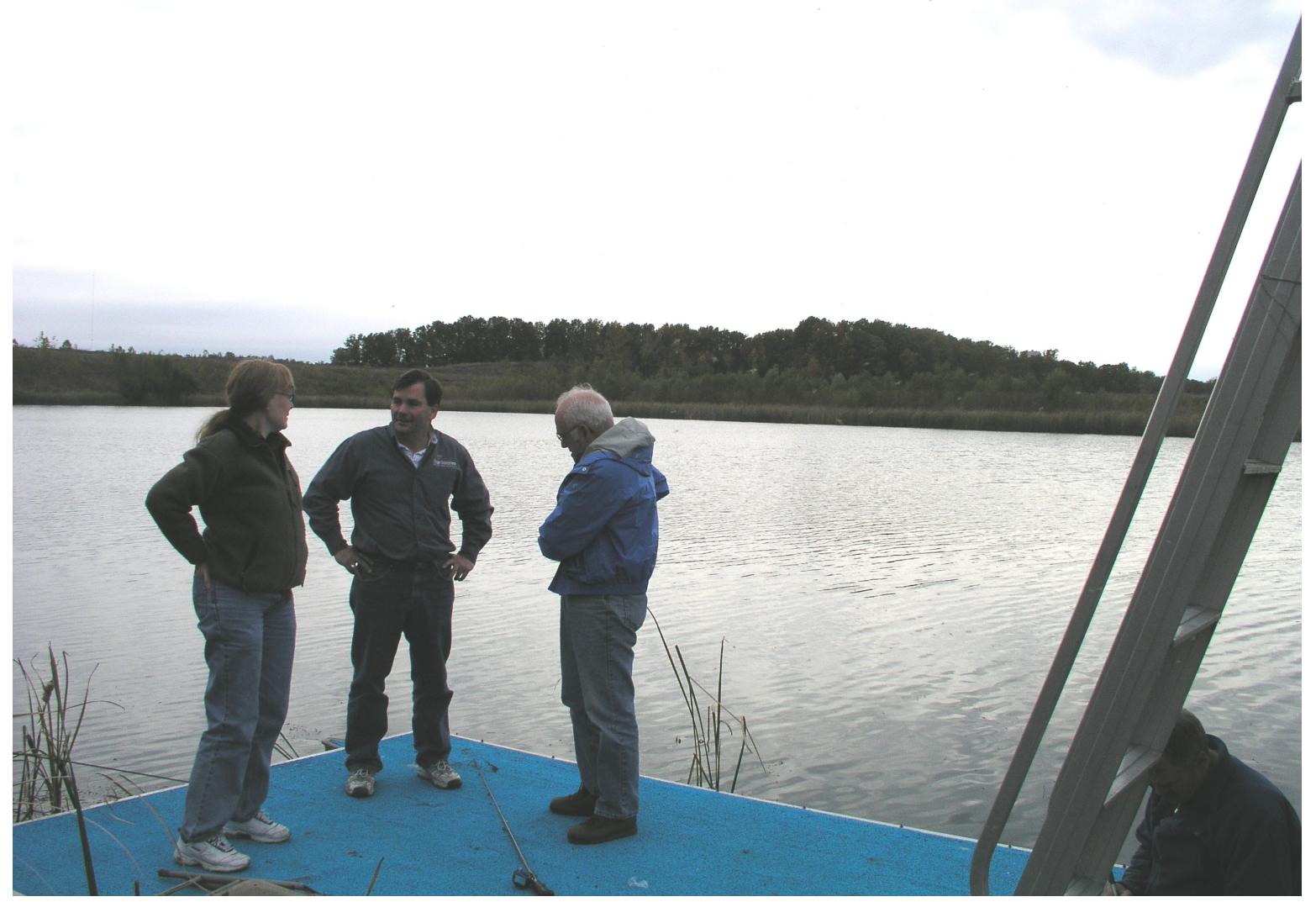

Figure 3. Tailings lake, Pea Ridge Mine, site of water sample $08 \mathrm{MO03}$ (C.M. Seeger, J. Kennedy, and A.N. Mariano (left to right), P.L. Verplanck kneeling far right).

\section{Results}

\section{Core and Pulp}

Lanthanide-plus-Y distribution patterns for pipe X11 samples (PR-1 through PR-9) generally are similar to each other (fig. 4). The exceptions are the Y-controlled downward turn of the patterns of the two REE+Y-rich samples (PR-5, PR-9) and sample PR-10. The latter sample contains at least 85 percent diopside and has a distinctly different pattern, displaying a more positively inclined slope on the heavy REE side of the pattern than those of the other samples. The pulp sample (PR-11), which we think was generated from the X11 pipe, has a pattern and concentration that is intermediate between the two high-grade samples and the iron ore and gangue samples. Our data compare favorably with published work and data generated for the previous mine owners. Composite assays of REE $+\mathrm{Y}+\mathrm{Th}$ concentrations for each of the four breccia pipes are listed in table 3. Derivative REE $+Y$ patterns are compared to our pipe X11 data in figure 5 (company data in table 3 are from an internal, hand-written, memo by Larry Tucker dated 10/25/89, copy provided by Jim Kennedy (electronic commun., October, 2008). The company assays were performed predominantly by Skyline Labs Inc., of Tucson, Arizona (assay reports provided by Doe Run Mining Company to MGS as part of a cooperative research and mapping program). A REE pattern for grab samples from pipe X13 also is shown in figure 5 (data from Nuelle and others, 1992). The patterns are all similar, especially in consideration of the probable use of different analytical techniques. Our data and those of Nuelle and others (1992) are consistent with, but 
do not confirm, the REE distributions and concentrations used by Larry Tucker in his calculation of reserves [internal, hand-written, memo by Larry Tucker dated 11/28/88, copy provided by Jim Kennedy (electronic commun., October, 2008)].

Our density data (table 1) for samples PR-5 and PR-11 (3.83 g/ $\mathrm{cm}^{3}$ and $3.40 \mathrm{~g} / \mathrm{cm}^{3}$ respectively) are consistent with, but do not confirm, the value of approximately $3.56 \mathrm{~g} / \mathrm{cm}^{3}$ used by Tucker in his reserve calculation for lanthanide ore (Tucker memo of 11/28/88). Magnetite ore, samples PR-7 and PR-8 (table 1), have densities of $4.44 \mathrm{~g} / \mathrm{cm}^{3}$ and $4.93 \mathrm{~g} / \mathrm{cm}^{3}$, respectively, which are consistent with the value of $2,000 \mathrm{lb} / 7 \mathrm{ft}^{3}$ (approx. $4.58 \mathrm{~g} / \mathrm{cm}^{3}$ ) used by Tucker in his calculations for magnetite ore reserves at the Pea Ridge Mine (Larry J. Tucker, electronic commun., September 25, 2009).

Table. 3 Composite REE+Y concentrations in percent of the four lanthanide-bearing pipes of the Pea Ridge deposit.

[\%, percent; na, not analyzed]

[Data from internal company memo by Larry J. Tucker, dated 10-25-89

(Jim Kennedy, electronic communication, October, 2008)]

\begin{tabular}{lcccc}
\hline Breccia pipe & $\mathrm{X}-11$ & $\mathrm{~V}-12$ & $\mathrm{X}-13$ & $\mathrm{~V}-14$ \\
\hline Element & & & & \\
\hline $\mathrm{La}$ & 4.45 & 2.70 & 2.95 & 2.05 \\
$\mathrm{Ce}$ & 8.00 & 4.50 & 4.95 & 4.05 \\
$\mathrm{Pr}$ & 0.68 & na & 0.41 & 0.34 \\
$\mathrm{Nd}$ & 2.15 & na & 1.50 & 1.10 \\
$\mathrm{Sm}$ & 0.42 & na & 0.33 & 0.24 \\
$\mathrm{Eu}$ & 0.03 & na & 0.03 & 0.02 \\
$\mathrm{Gd}$ & 0.15 & na & 0.18 & 0.08 \\
$\mathrm{~Tb}$ & na & na & na & na \\
$\mathrm{Dy}$ & 0.19 & na & 0.18 & 0.09 \\
$\mathrm{Ho}$ & 0.03 & na & 0.03 & 0.01 \\
$\mathrm{Er}$ & 0.09 & na & 0.09 & 0.04 \\
$\mathrm{Tm}$ & na & na & na & na \\
Yb & 0.16 & na & 0.12 & 0.06 \\
$\mathrm{Lu}$ & 0.02 & na & 0.01 & na \\
$\mathrm{Y}$ & 0.70 & 0.69 & 0.67 & 0.36 \\
$\mathrm{Th}$ & 0.63 & na & 0.23 & 0.41 \\
\hline
\end{tabular}




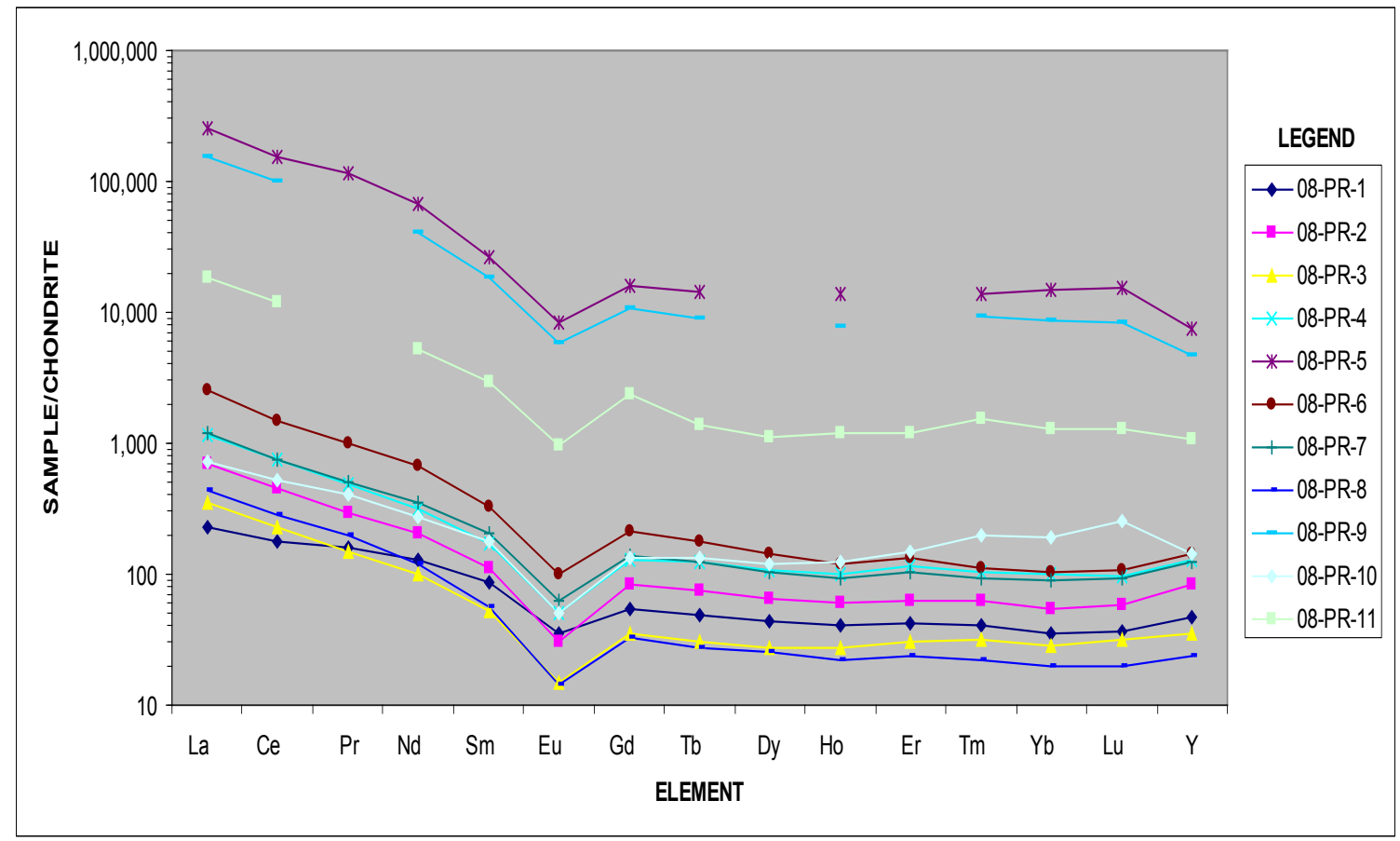

Figure 4. Chondrite normalized $R E E+Y$ distribution patterns of core and pulp samples. In this figure and subsequent figures showing $R E E+Y$ distribution patterns, the gaps in the patterns are the due to reported qualified concentration values for individual elements (that is values reported as greater than) or to the absence of reported values for individual elements. Chondrite values are from Wakita and others (1971).

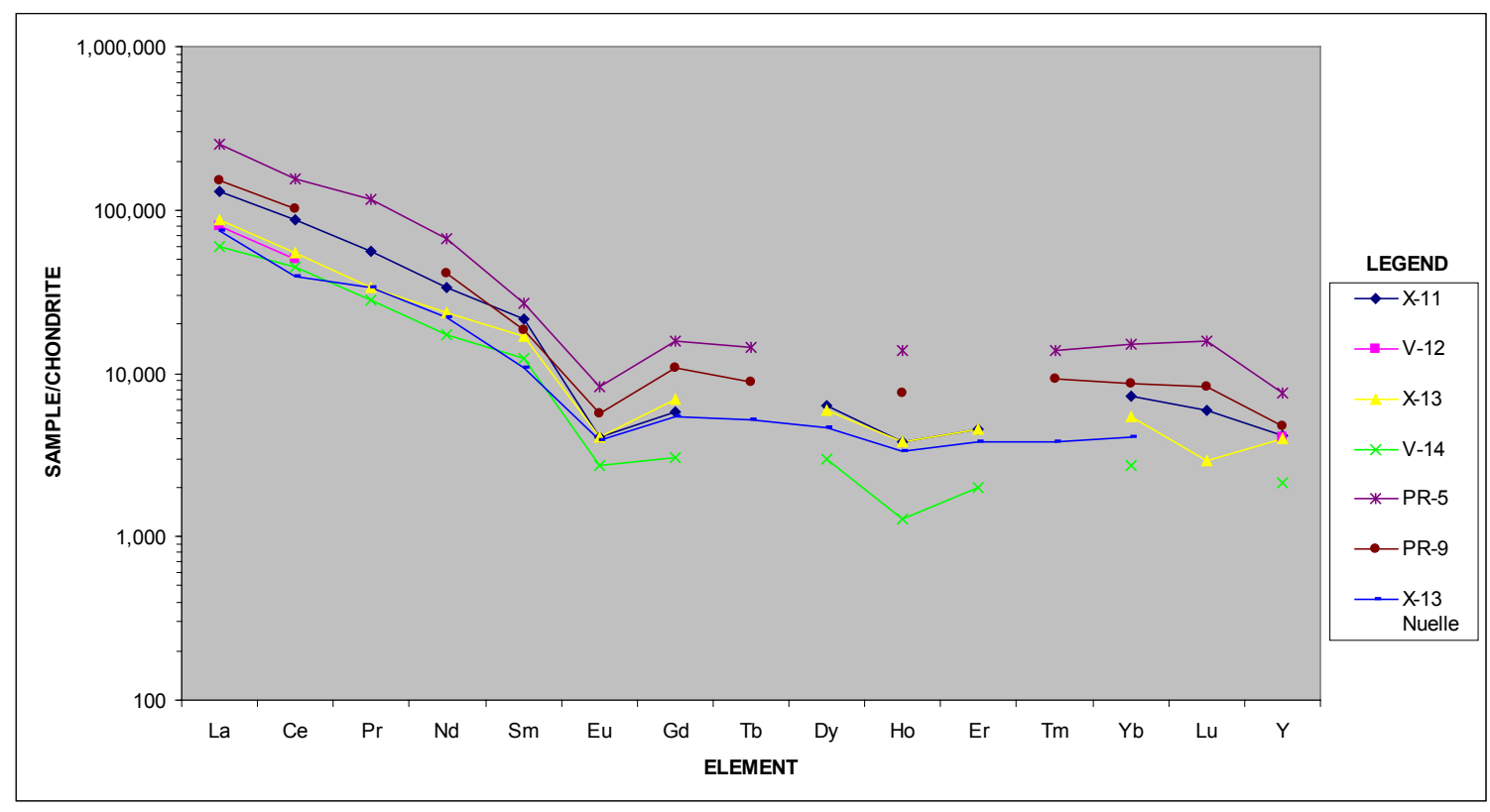

Figure 5. Chondrite normalized $R E E+Y$ distribution patterns of samples from the four lanthanide-bearing breccia pipes of the Pea Ridge deposit. Data for X-11, V-12, X-13, V-14 from memo by Larry Tucker dated 11/28/88; data for X-13-Nuelle from Nuelle and others, 1992; data for other samples from table 1 [see tables 1 and 3 for sample descriptions]. Chondrite values are from Wakita and others (1971). 


\section{Tailings}

The REE+Y patterns (fig. 6) for the three tailings samples are similar to our Fe-rich samples. The elevated concentrations of REE and Y agree with the data of Vierrether and Cornell (1993), which led them to suggest a REE recovery circuit for the tailings. The circuit is based on the experimental development of a recovery scheme for breccia pipe ores (Whitten and Yancey, 1990) and successful production of phosphate concentrates by the Pea Ridge Iron Ore Company.

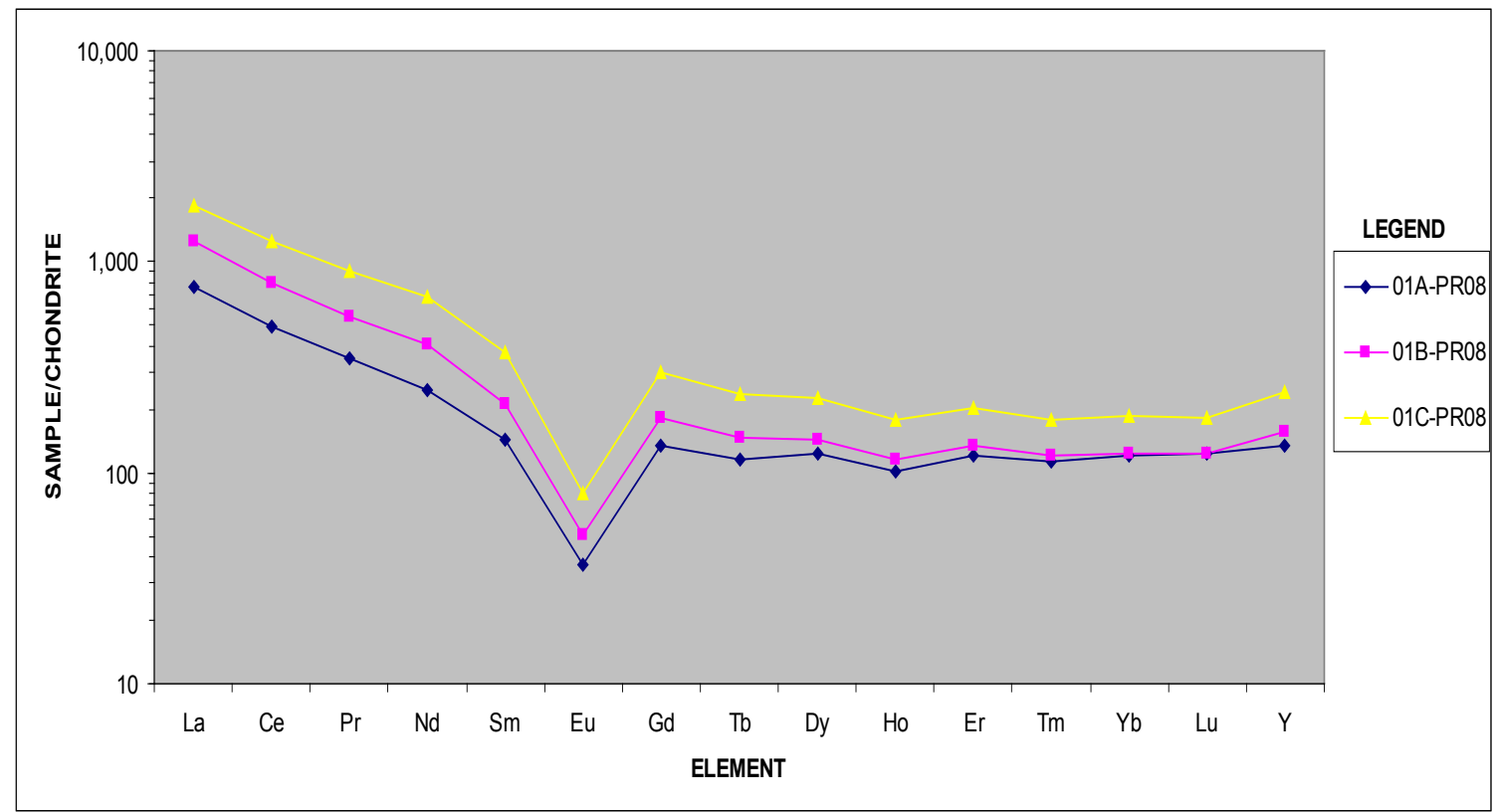

Figure 6. Chondrite normalized $R E E+Y$ distribution patterns of three tailings samples from the Pea Ridge deposit. Data from table 1. Chondrite values are from Wakita and others (1971).

\section{Water from Tailings Lake and Pools}

The REE + Y patterns of the three water samples (table 2) are similar to each other (fig. 7) and are much flatter than the patterns of the core and tailings samples. The samples from the small pools have lower $\mathrm{pH}$ than the lake sample and higher $\mathrm{REE}+\mathrm{Y}$ concentrations, suggesting a $\mathrm{pH}$ affect on the concentration. Two processes may be responsible for this observation: (1) increased dissolution of the $\mathrm{REE}+\mathrm{Y}$ bearing minerals in the tailings with decreasing $\mathrm{pH}$; and (2) loss of dissolved REEs with increasing $\mathrm{pH}$. Experimental data of Oelkers and Poitrasson (2002) show increasing solubility rates of monazite as a function of decreasing $\mathrm{pH}$ below neutrality. Their data and that of Schmidt and others (2006) indicate that both monazite and xenotime tend to dissolve incongruently, which could account for the flattened REE $+Y$ patterns of the water as compared to the rock samples. Some of the difference in total REE concentrations between these three samples also may be a function of partitioning of REEs from the aqueous to the solid phase with increasing $\mathrm{pH}$. Verplanck and others (2004) showed that as $\mathrm{pH}$ increased from $\mathrm{pH} 4$ to 6 , REEs tend to sorb onto iron precipitates, thus lowering the dissolved concentration of REEs. The low $\mathrm{pH}$ in the pools probably is because of the oxidation of sulfide minerals, which are unevenly dispersed in several of the units in the mine (Nuelle and others, 1992). 


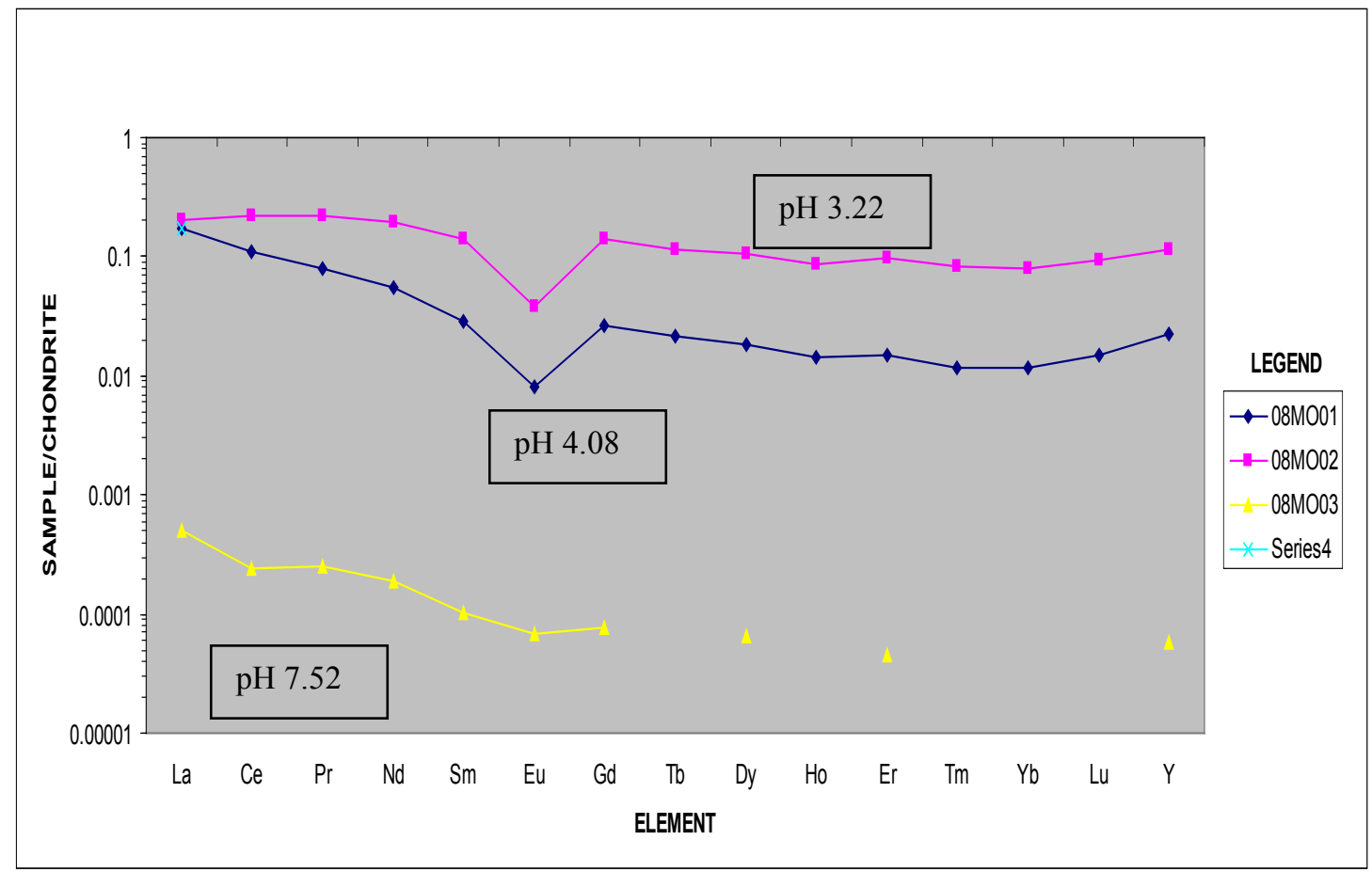

Figure 7. Chondrite normalized $R E E+Y$ distribution patterns of three water samples from Pea Ridge tailings lake and pool. Data from table 2. Chondrite values are from Wakita and others (1971).

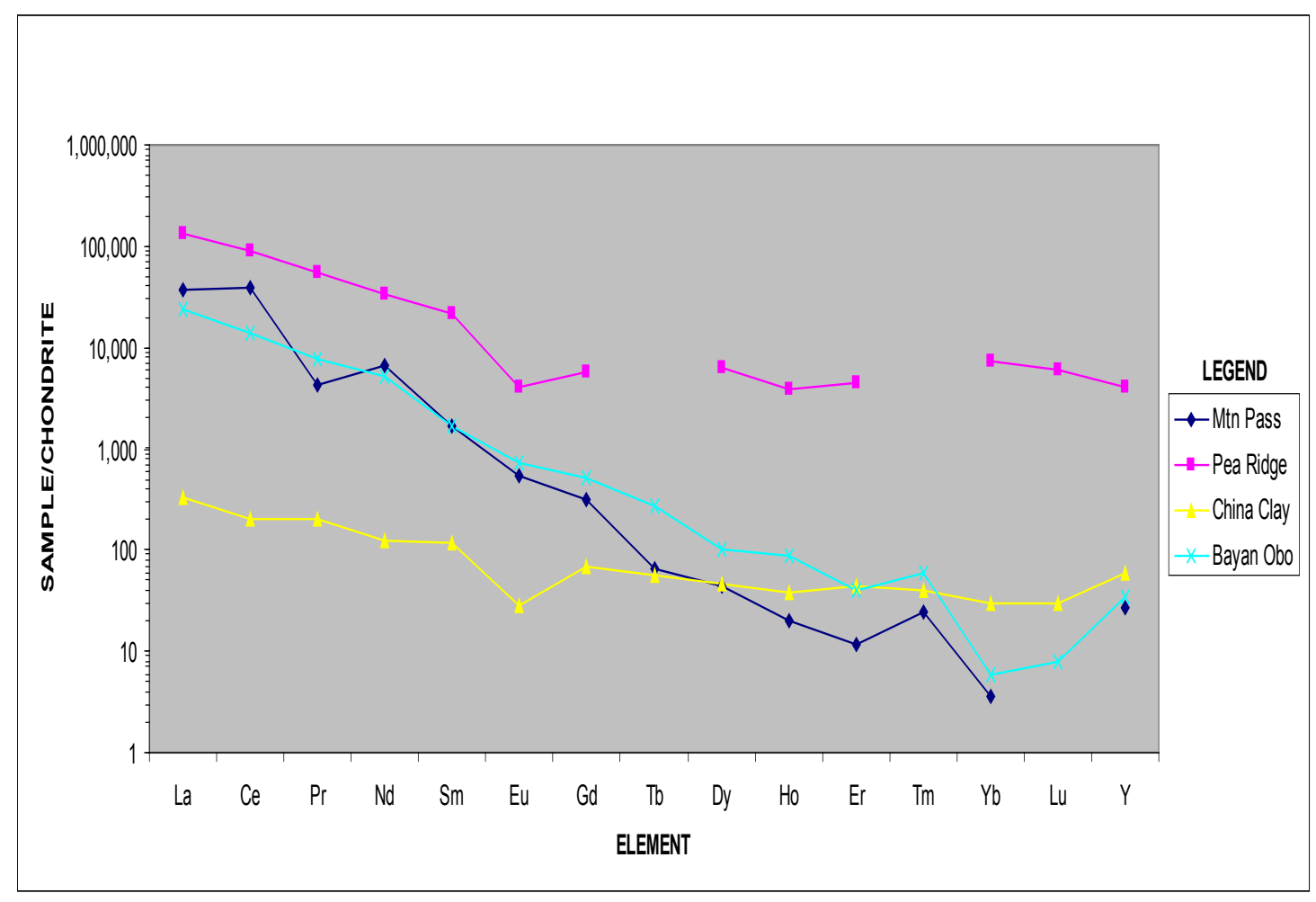

Figure 8. Chondrite normalized $R E E+Y$ distribution patterns of world-class lanthanide deposits and the Pea Ridge deposit. Data from table 4. Chondrite values are from Wakita and others (1971). 


\section{Comparison to World Class Lanthanide Deposits}

With increased demand for REE $+\mathrm{Y}$, anticipated greater need for middle to heavy REE, and decreasing REE exports from China, there is a need to find additional REE+Y resources and to evaluate deposits in terms of the REE distribution in the ore. The grade and tonnage values presented in this report (table 4) are for comparative purposes only; they are not compliant with any of the currently (Feb., 2010) accepted reporting standards such as the Canadian Standards of Disclosure for Mineral Projects (National Instrument 43-101) (http://www.msc.gov.mb.ca/legal_docs/legislation/notices/ni43101.pdf) and the Australasian Joint Ore Reserves Committee Code (JORC Code) (http://www.jorc.org/jorc_code.asp). The grade and tonnage values for the individual REE and Y are calculated from tonnage values of the entire deposit and published concentrations of individual elements in either mill feeds (Mountain Pass Rare Earth Deposit), hand samples (Bayan Obo Fe-Nb-REE deposit, China Clay Type Lanthanide Deposits), or drill pulps and hand samples (Pea Ridge deposit).

Two of the World's largest lanthanide deposits are the Bayan Obo Fe-Nb-REE deposit, Inner Mongolia, China and the Mountain Pass Rare Earth deposit, California. They contain approximately 48 million and 2.6 million metric tons of REE+Y oxides, respectively (Berger and others, 2009; Castor and Nason, 2004; Castor, 1991). However, these deposits are dominated by the light REE (table 4). The group of deposits known as China Clay Type Lanthanide Deposits often are cited as the largest known source of low-cost, heavy REE+Y (Grauch and Mariano, 2008). Collectively, the China Clays contain an estimated minimum of 1 million metric tons of REE+Y oxides (Clark and Shuhui Zheng, 1991). Despite its much smaller known reserve of REE+Y oxides (72,000 metric tons), the Pea Ridge deposit apparently contains more of the heavy REE and Y than the Mountain Pass deposit (table 4). The differences in $\mathrm{REE}+\mathrm{Y}$ distribution between the four deposits are shown in figure 8 . The flatter patterns for the China Clay and Pea Ridge deposits reflect their relative enrichment in heavy REE $+\mathrm{Y}$. 
Table 4. REE $+Y$ oxide concentrations in metric tons of three world-class lanthanide deposits and the Pea Ridge deposit.

\begin{tabular}{lcccc}
\hline Deposit & Bayan Obo & Mountain Pass & China Clay & Pea Ridge \\
\hline Oxide & \multicolumn{4}{c}{} \\
\hline $\mathrm{La}_{2} \mathrm{O}_{3}$ & $15,267,052$ & 872,120 & 193,001 & 18,275 \\
$\mathrm{Ce}_{2} \mathrm{O}_{3}$ & $23,720,328$ & $1,279,918$ & 311,762 & 32,298 \\
$\mathrm{Pr}_{2} \mathrm{O}_{3}$ & $1,734,339$ & 106,337 & 40,529 & 2,862 \\
$\mathrm{Nd}_{2} \mathrm{O}_{3}$ & $6,083,552$ & 288,040 & 135,197 & 9,474 \\
$\mathrm{Sm}_{2} \mathrm{O}_{3}$ & 616,088 & 21,939 & 38,165 & 1,963 \\
$\mathrm{Eu}_{2} \mathrm{O}_{3}$ & 99,822 & 2,710 & 3,430 & 158 \\
$\mathrm{Gd}_{2} \mathrm{O}_{3}$ & 247,460 & 5,420 & 29,699 & 808 \\
$\mathrm{~Tb}_{2} \mathrm{O}_{3}$ & 23,884 & 413 & 4,282 & $\mathrm{nd}$ \\
$\mathrm{Dy}_{2} \mathrm{O}_{3}$ & 56,584 & 878 & 22,994 & 903 \\
$\mathrm{Ho}_{2} \mathrm{O}_{3}$ & 12,594 & 103 & 4,918 & 137 \\
$\mathrm{Er}_{2} \mathrm{O}_{3}$ & 14,270 & 155 & 14,401 & 430 \\
$\mathrm{Tm}_{2} \mathrm{O}_{3}$ & 3,376 & 52 & 2,059 & nd \\
$\mathrm{Yb}_{2} \mathrm{O}_{3}$ & 2,364 & 52 & 10,755 & 662 \\
$\mathrm{Lu}_{2} \mathrm{O}_{3}$ & 490 & nd & 1,627 & 88 \\
$\mathrm{Y}_{2} \mathrm{O}_{3}$ & 117,798 & 3,355 & 187,181 & 3,942 \\
$\mathrm{sum}^{4}$ & $48,000,000$ & $2,581,490$ & $1,000,000$ & 72,000 \\
\hline
\end{tabular}

\section{Mountain Pass deposit}

Estimated reserves of 29 million metric tons of ore at 8.9 percent $\mathrm{RE}_{2} \mathrm{O}_{3}$ with a 5 percent cutoff (Castor and Nason, 2004 (p. 70).

REE distribution calculated from data in Castor (2008) for $\mathrm{RE}_{2} \mathrm{O}_{3}$ in concentrate (assumes REE $+Y$ distribution in the concentrate is similar to that in the ore).

\section{Bayan Obo deposit}

800 million metric tons of ore at 6 percent $\mathrm{RE}_{2} \mathrm{O}_{3}$, Berger and others (2009).

REE distribution based on the average of three highly mineralized carbonatite samples from the east ore deposit (Xiao-Yong Yang and others, 2009).

\section{China Clay deposits}

Estimated minimum of 1 million metric tons contained $\mathrm{RE}_{2} \mathrm{O}_{3}$ (Clark and Shuhui, 1991).

REE distribution based on a single ore sample, Grauch and Mariano (2008) and unpublished data.

\section{Pea Ridge deposit}

600,000 metric tons of reserves with an average tenor of 12 percent $\mathrm{RE}_{2} \mathrm{O}_{3}$ (Whitten and Yancy, 1990).

REE distrubution is based on the average of composite assays of samples from four breccia pipes, memo by Larry J. Tucker dated 10-25-89 (Jim Kennedy, electronic communication, October, 2008). 


\section{Conclusions}

Analytical data for a limited number of hand samples from the Pea Ridge deposit are consistent with, but do not confirm, some of the company data used in calculations of lanthanide and magnetite ore grade and reserves. The Pea Ridge lanthanide resource is high grade and enriched in heavy REE $+\mathrm{Y}$ as compared to world class lanthanide deposits such as Bayan Obo (China), Mountain Pass (California), and the South China Clay Type Lanthanide Deposits (southern China). However, the open-ended, probable REE $+Y$ reserve of Pea Ridge is smaller in comparison to the others.

\section{Acknowledgements}

We thank Jim Kennedy, president of Wings Enterprises Inc., for his hospitality and willingness to share samples and data. Larry J. Tucker (consultant and retired Pea Ridge Mine superintendent, Sullivan, Missouri) provided insights from his time in the mine and has kindly shared his knowledge of ore reserves. The Missouri Department of Natural Resources, Division of Geology and Land Survey (DGLS) generously shared core material from its McCracken Core Library in Rolla, Missouri. Thanks to David Fey and David Detra who made valuable suggestions for improving an earlier version of this manuscript. Anthony N. Mariano (consultant, Carlisle, Massachusetts) was, as always, an enjoyable travel companion and an endless source of ornithological insights as well as information on lanthanide deposits of the world.

\section{References Cited}

Barringer, J.L., and Johnsson, P.A., 1989, Theoretical considerations and a simple method for measuring alkalinity and acidity in low-pH waters by gran titration: U.S. Geological Survey WaterResources Investigations Report 89-4029, 35 p.

Berger, V.I., Singer, D.A., and Orris, G.J., 2009, Carbonatites of the world, explored deposits of Nb and REE-Database and grade and tonnage models: U.S. Geological Survey Open-File Report 20091139, 17 p. and database. (Also available at http://pubs.usgs.gov/of/2009/1139/).

Briggs, P.H., 2002, The determination of twenty-seven elements in aqueous samples by inductively coupled plasma-atomic emission spectrometry, in Taggart, J.E., Jr., ed., Analytical methods for chemical analysis of geologic and other materials, U.S. Geological Survey: U.S. Geological Survey Open-File Report 02-223, chapter F, 11 p. (Also available at http://pubs.usgs.gov/of/2002/ofr-020223/F0203ICPAES_M.pdf).

Budahn, J.R., and Wandless, G.A., 2002, Instrumental neutron activation by long count, in Taggart, J.E., Jr., ed., Analytical methods for chemical analysis of geologic and other materials, U.S. Geological Survey: U.S. Geological Survey Open-File Report 02-223, chapter X, 13 p. (Also available at http://pubs.usgs.gov/of/2002/ofr-02-0223/X14INAALong_M.pdf).

Castor, S.B., 1991, Rare earth deposits in the southern Great Basin, in Raines G.I., Lisle R.E., Shafer, R.W., and Wilkinson W.H., eds., Geology and ore deposits of the Great Basin I: Geological Society of Nevada Symposium Proceedings, Reno, p. 523-528.

Castor, S.B., 2008, The Mountain Pass rare-earth carbonatite and associated ultrapotassic rocks, California: The Canadian Mineralogist, v. 46, p. 779-806.

Castor, S.B., and Nason, G.W., 2004, Mountain Pass Rare Earth Deposit, California, in Castor, S.B., Papke, K.G. and Meeuwig, R.O., eds., Proceedings of the 39th Forum on the Geology of Industrial Minerals: Nevada Bureau of Mines and Geology Special Publication 33, p. 68-81. 
Clark, A.L., and Shuhui Zheng, 1991, China's rare earth potential, industry and policy, in Siribumrungsukha, B., Arrykul, S., Sanguansai, P., Pungrassami, T., Sikong, L., and Kooptarnond, K., eds., Proceedings of International Conference on Rare Earth Minerals and Minerals for Electronic Uses, January 23-25, 1991: Prince of Songkla University, Hat Yai, Thailand, p. 577-601.

Grauch, R.I. and Mariano, A.N., 2008, Ion-adsorption type lanthanide deposits [abs]: Society of Mining, Metallurgy and Exploration Annual Meeting and Exhibit Preliminary Program, p. 40.

Hunt, G.R., Johnson, G.R., Olhoeft, G.R., Watson, D.E., and Watson, K., 1979, Initial report of the petrophysics laboratory: U.S. Geological Survey Circular 789, $74 \mathrm{p}$

Husman, J.R., 1989, Gold, rare earth element, and other potential by-products of the Pea Ridge iron ore mine, Washington County, Missouri (Contribution to Precambrian Geology No. 21): OFR-89-78-MR, $18 \mathrm{p}$.

Lamothe, P.J., Meier, A.L., and Wilson, S.A., 2002, The determination of forty-four elements in aqueous samples by inductively coupled plasma-mass spectrometry, in Taggart, J.E., Jr., ed., Analytical methods for chemical analysis of geologic and other materials, U.S. Geological Survey: U.S. Geological Survey Open-File Report 02-223, chapter H, 13 p. (Also available at http://pubs.usgs.gov/of/2002/ofr-02-0223/H21\&23OFR99-151_M.pdf).

Meier, A.L., Grimes, D.J., and Ficklin, W.H., 1994, Inductively coupled plasma-mass spectrometry-A powerful analytical tool for mineral resource and environmental studies [abs], in Carter, L.M.H., Toth, M.I., and Day, W.C., eds., U.S. Geological Survey Research on Mineral Resources-1994, Part A-Program and Abstracts, Ninth V.E. McKelvey Forum on Mineral and Energy Resources: U.S. Geological Survey Circular 1103-A, p. 67-68.

Nuelle, L.M., Day, W.C., Sidder, G.B., and Seeger, C.M., 1992, Geology and mineral paragenesis of the Pea Ridge Iron Ore Mine, Washington County, Missouri — Origin of the rare-earth-element- and gold-bearing breccia pipes: U.S. Geological Survey Bulletin 1989 A-C, p. A1-A11.

Oelkers, E.H., and Poitrasson, F., 2002, An experimental study of the dissolution stoichiometry and rates of a natural monazite as a function of temperature from 50 to $230{ }^{\circ} \mathrm{C}$ and $\mathrm{pH}$ from 1.5 to 10 : Chemical Geology, v. 191, p. 73-87.

Schmidt, C., Rickers, K., Bilderbeck, D.H., and Rong Huang, 2006, In situ synchrotron-radiation XRF study of REE phosphate dissolution in aqueous fluids to $800^{\circ} \mathrm{C}$ : Lithos, v. 95 , p. 87-102.

Seeger, C.M., Nuelle, L.M., Day, W.C., Sidder, G.B., Marikos, M.A., and Smith, D.C., 2001, Geologic maps and cross sections of mine levels at the Pea Ridge Iron Mine, Washington County, Missouri: U.S. Geological Survey Miscellaneous Field Studies Map MF-2353, 5 sheets, 6 p. (Also available at http://greenwood.cr.usgs.gov/pub/mf-maps/mf-2353/).

Seeger, C.M., 2004, Geology and mineralogy of rare earth element-bearing breccia pipes, Pea Ridge Mine, Missouri, in Seeger, C.M., ed., Proceedings of the $38^{\text {th }}$ Forum on the Industrial Minerals: Missouri Department of Natural Resources, Geological Survey and Resource Assessment Division, Report of Investigations No. 74, p. 247-259.

Sidder, G.B., Day, W.C., Nuelle, L.M., Seeger, C.M., and Kisvarsanyi, E.B., 1993, Mineralogic and fluid-inclusion studies of the Pea Ridge iron-rare-earth-element deposit, southeast Missouri: U.S. Geological Survey Bulletin 2039, p. 205-216.

Suzuki, S., and Hirai, S., 1987, Instrumental neutron activation analyses of vehicle exhaust particulates as environmental reference material: Analytical Sciences, v. 3, p. 193-197.

Taggart, J.E., Jr., and Siems, D.F., 2002, Major element analysis by wavelength dispersive X-ray fluorescence spectrometry, in Taggart, J.E., Jr., ed., Analytical methods for chemical analysis of geologic and other materials: U.S. Geological Survey: U.S. Geological Survey Open-File Report 02223, chapter T, 9 p. (Also available at http://pubs.usgs.gov/of/2002/ofr-02-0223/T16WDXRF_M.pdf). 
Verplanck, P.L., Nordstrom, D.K., Taylor, H.E., and Kimball, B.A., 2004, Rare earth element partitioning between iron oxyhydroxides and acid mine waters: Applied Geochemistry, v. 19, p. 13391354.

Vierrether, C.W., and Cornell, W.L., 1993, Rare-earth occurrences in the Pea Ridge tailings: U.S. Bureau of Mines Report of Investigations 9453, 10 p.

Wakita, H., Rey, P., and Schmitt, R.A., 1971, Abundances of the 14 rare-earth elements and 12 other trace elements in Apollo 12 samples - Five igneous and one breccia rocks and four soils:

Proceedings of Second Lunar Science Conference, The MIT Press, p.1319-1329.

Whitten, C.W., and Yancey, R.J., 1990, Characterization of the rare-earth mineralogy at the Pea Ridge deposit, Missouri: Bureau of Mines Report of Investigations 9331, p. 9.

Williams, J.P., Barton, M.D., Johnson, D.A., Fontboté, Lluís, deHaller, Antoine, Mark, Gordie, Oliver, H.S., and Marshik, Robert, 2005, Iron oxide copper-gold deposits - Geology, space-time distribution, and possible modes of origin, in Hedenquist, J.W., Thompson, J.F.H., Goldfarb, R.J., Richards, J.P., eds., Economic Geology $100^{\text {th }}$ Annivesary Volume: Society of Economic Geologists, Littleton, Colo., p. 371-405.

Xiao-Yong Yang, Wei-Dong Sun, Yu-Xu Zhang, and Yong-Fei Zheng, 2009, Geochemical constraints on the genesis of the Bayan Obo Fe-Nb-REE deposit in Inner Mongolia, China: Geochimica et Cosmochimica Acta, v. 73, p. 1417-1435. 